\title{
Agro Based Industries Loan Operation and Contribution in GDP of Bangladesh: A Case Study on Rajshahi Krishi Unnayan Bank (RAKUB)
}

\author{
Md. Ashfaqur Rahman ${ }^{1}$, Md. Moyazzem Hossain ${ }^{2}$ \\ ' (Mia Jinnah Alam Degree College, Bangladesh) \\ ${ }^{2}$ (Department of Statistics, Islamic University, Bangladesh)
}

\begin{abstract}
Agro based industries are highly potential in the development of Bangladesh through government support with the financial aids along with training facilities for development in this sector. The aim of this paper is to identify the relations of Agro based industries loan to other loans. Also this paper identifies the contribution of the loans on different agricultural sectors in Gross Domestic Product (GDP) of Bangladesh. The study is confined only to the specific areas like the loans on different agricultural sectors and the contribution to GDP by the agriculture sector by the Rajshahi Krishi Unnayan Bank for the twelve years period starting from 1998-1999 to 2009-2010. This paper investigate that all the variables considered in this study are positively correlated to each other. The coefficient of the regression line showed that there was a significant positive association between the contribution in GDP by agriculture and the loans on Crops, Livestock, Fishery, Irrigation equipment \& farm machinery and Agro based industries.
\end{abstract}

Keywords : Rajshahi Krishi Unnayan Bank, Agro based industries loan, GDP, Bangladesh

\section{INTRODUCTION}

The major occupation of the people of Bangladesh is "Krishi". Krishi is a Bengali word which means "Agriculture". About $85 \%$ of the population depends directly or indirectly on agriculture which contributes a significant portion to GDP. Agriculture is the single largest producing sector of the economy since it comprises about $30 \%$ of the country's GDP and employs around $60 \%$ of the total labor force (http://en.wikipedia.org/ wiki/Agriculture_in_Bangladesh). The performance of this sector has an overwhelming impact on major macroeconomic objectives like employment generation, poverty alleviation, human resources development and food security. So the proper development of the country cannot be thought of without the proper development of its agricultural sector. In this respect, the banking system acts as a major contributor for the development of this agricultural sector.

The bank undertook special scheme to intensify financial support for establishment and expansion of agro-based industries and exploiting infrastructural advantage and availability of huge raw materials of the northwest region of the country. The government also approves establishment of ago-based industries and provides additional fund to banks and financial institutions. To best utilize the above opportunities the bank has taken pragmatic steps to enthuse potential entrepreneurs for establishing agro-based industries for preservation and processing of agricultural products of this region of the country, famous for production of quality raw materials. The bank emphasizes financing in small industries instead of a few large ones. Recently set three tiers 'credit committee' at the head office, divisional office and zonal offices provide necessary support and advice to the intending entrepreneurs.

In a developing country like Bangladesh, the banking system, as a whole, plays a vital role in the progress of its economic development. A bank, as a matter of fact, is just like the heart in the economic structure and the capital provided by bank is just like the blood in it. As it is mentioned already that the economy of Bangladesh is mainly dominated by agriculture, that is why if the finance is not provided to the agricultural sector, the growth of the economy will be slowed down. Loan facility provided by the bank works as an incentive to the producer to increase production (http://www.blurtit.com/q 197532.html). Keeping this in mind, for the purpose of the development of agricultural sector, the Government of Bangladesh has established two specialized banks - namely: Bangladesh Krishi Bank (BKB) and Rajshahi Krishi Unnayan Bank (RAKUB). These banks are continuously trying to provide support for the advancement and development of the agricultural sector of the country. First of all, they are promoting savings, mostly from middle and lower middle class of urban and rural people. Secondly these banks promote investment in different sectors of agriculture, industry and trade. They either invest directly or advances loan to the investors. They are continuously helping the disadvantaged people to become self sufficient by providing them micro credit.

Rajshahi Krishi Unnayan Bank (RAKUB) is a state-owned bank in Bangladesh with regional approach. The bank emerged as the government's plan of intensive care to agriculture of Rajshahi and Rangpur 
administrative divisions providing livelihood to 35 million people of the area. The region is less developed compared to other parts, yet full of potentials in agriculture. Rajshahi and Rangpur divisions characterized by its surplus food grain production are popularly called the "granary of the country". Besides catering to agricultural credit, RAKUB, as it is acronymed, renders deposit banking services through all the 374 branches. The headquarters of the bank is stationed at Rajshahi city, some 270 kilometer to the north of Dhaka. As the largest development partner in agriculture of the northwest region RAKUB aims at overall development of farmers and all the sectors and sub-sectors of agriculture in this region. The bank also performs functions like financing agribusiness and agro-based industries and poverty alleviation programs. Present authorized capital of the bank amounts to Tk 7500 million and paid-up capital Tk 5700 million. Reserves stand at Tk 208.50 million as on 31 Decembar 2012 (http://www.rakub.org.bd).

RAKUB also gives importance to accumulation of rural small savings through its branches. RAKUB renders all sorts of deposit banking services to its over one million valued customers. The Bank operates deposit accounts like Savings Bank Accounts, Current Deposit Accounts, Short Term Deposit Accounts and Fixed Deposit Accounts. The poverty stricken area of north-west Bangladesh is characterized by comparatively lower rate of savings, inadequate capital accumulation and slim employment opportunities. The existing collateralbased banking system is also of little use in respect of extending support to the millions of landless people. To address the problem, the Bank has been financing collateral-free micro-credit for income and employment generation through its poverty alleviation credit programs. The Bank finances for production of all the summer and winter crops, horticulture \& nursery etc. It extends credit facilities for systematic and commercial livestock farming which includes dairy, beef-fattening, poultry, raising and setting up of hatcheries which in turn is expected to increase production of milk, meet and eggs, the main source of protein. In today's technology-based farming of high yielding and high-value crops, mechanization of cultivation, irrigation and pest-control is indispensable. To cope with the situation, the Bank also provides financing for power tillers, tractors, tube wells, power-pumps and fertilizer and pesticide application devices. Agro-industries for import sub situation are specially encouraged by offering moderate terms of financing. These agro based industries are - poultry farm, dairy farm, food processing plant, fish freezing/processing industries, leather process and leather based products item, vegetables etc. (Mahumud et al. 2013).

During FY10, global economic recovery proceeded broadly as expected on two-track pace, with generally high robust output growth in emerging and developing economies and lower in many of the mature developed western economies beset by lingering financial sector weaknesses impeding lending and job creation, slow demand recovery in households deleveraging debt burdens. This was compounded further by concerns of markets about high public debt levels of some of the western developed economies. Continuing her resilient response to the global economic slowdown, the Bangladesh economy maintained growth momentum, with some slowdown in export growth and in new investment activities. Impact of the slowdown on Bangladesh economy showed up with some lags from early FY09, with downturns in exports, imports and new investment activities. Outlays from national budget provided support to the affected sectors and extended the social safety net to uphold domestic demand and economic activities. Bangladesh Bank maintained a financial inclusion focused growth supportive monetary policy stance to help maintain momentum in economic activities. Supported by these policy measures, real GDP, estimated by Ministry of Planning, grew by 5.8 percent in FY10 against 5.7 percent growth in FY09. Agriculture sector output growth was 4.7 percent, industry sector output growth was 6.0 percent and service sector output growth was 6.4 percent in FY10 against 4.1, 6.5 and 6.3 percent growth in these sectors respectively in FY09. The agriculture sector which accounts for 20.2 percent of GDP grew by 4.7 percent in FY10 higher than 4.1 percent in FY09. In the National Budget top priority has been accorded to agriculture and rural development. As part of its proactive policy to boost up agricultural production, BB declared its annual agricultural credit policy and programme for FY10 with a gigantic disbursement target of Tk 115.12 billion. Achievement against this target was 96.57 percent (Annual Report, RAKUB, 2009-10). The aim of this paper is to identify the relations of Agro based industries loan to other loans. Also this paper identifies the contribution of the loans on different agricultural sectors in Gross Domestic Product (GDP) of Bangladesh.

The rest of the paper is organized as section 2 discusses the literature review. Section 3, contains the methodology of this study. Results and discussion are given in section 4. Finally section 5, contains the conclusion with some suggestions.

\section{LITERATURE REVIEW}

Agri finance is very important in the development of Bangladesh economy. Agriculture Financing may be defined as money lent at interest or on profit for agricultural activities. Agri businesses require three types of investment a) short term trading purpose b) working capital (short term investment), c) financing for export \& import purposes (Afroz Nushrat Nahida, 2012). The Food and Agricultural Organization (FAO) mentions that: For many of the currently more than 1.1 billion people that are living in extreme poverty, economic growth based primarily on agriculture and on non-farm rural activities. Agricultural finance is essential to improve their 
livelihoods. Agricultural growth gives better access to land, water, credit, health and education for rural people that alleviate poverty and hunger (http://en.wikipedia.org). Chowdhury and Islam (2007) showed that deposits and loan and advances of Specialized Banks (SBs) are more sensitive to interest rate changes than those of Nationalized Commercial Banks (NCBs). So SBs should not make abrupt change in lending rate and deposit rate by following the NCBs. If NCBs change their lending rate or deposit rates, their deposits and loan and advances will be affected less than those of SBs. However, SBs offer higher deposit rate and charge higher lending rates than NCBs. That is why the interest rate spared of SBs was higher than that of NCBs.

T. A. Chowdhury and S. S. Chowdhury, (2011) have analyzed the development and growth of specialized agricultural banks in Bangladesh and the different services and facilities they are providing for the overall improvement of this sector. It is observed that both agricultural banks are able to achieve a steady growth in terms of employees, branches, deposits, loans and advances. According to Farid Ahmed M. (1980) though Bangladesh inherited an agrarian economy, agriculture did not get due importance hitherto. As such the farmers did not find change of their lot, rather the number of landless and marginal farmers increase day by day. The main drawback of our agriculture is the lack of finance as the vast majority of our farmers are living at or below subsistence level. These farmers were found to receive $86 \%$ of their credit from non institutional sources which includes money lenders, shopkeepers, relatives, friends, well to do rural people, market intermediaries and others. It was guessed that non institutional sources still provide $70 \%$ of the credit. In this regard institutional credit facility can be considered. Institutional sources refer to the government, cooperatives, agricultural banks, and commercial banks etc. that are entrusted with the responsibility of credit dispensing. Institutional sources provide an increasing trend with the passage of time.

The effectiveness of lending program of Rajshahi Krishi Unnayan Bank analyses in promoting agriculture, rural development and development of agro- industrial base (Paul, Priya, Brata, 1989). Agro based industries are highly important for the employment opportunities and income generating activities. BKB is a significant financial institution in rural credit of Bangladesh. It has got a pivotal role to play in developing an agricultural sector in Bangladesh. (Zahural Alam et al., 2008). Various industries are involved in agro based industries such as rice mills, flower mills, ice power plant, possessing and marketing of agro products etc. Of the total agricultural credit, Bangladesh Krishi Bank (BKB) disbursed 55.4 percent, participating commercial banks and financial institutions including Bangladesh Rural Development Board 29.8 percent and Bangladesh Samabaya Bank limited 5.3 percent (Ahmed, S., 1988).

According to Khalily, Huda and Lalarukh (1997), credit is necessary for agricultural development visà-vis rural economic development. But loan recovery rate is low. This has adverse impact on revolving of loan able fund and viability of rural financial system. Poor performance of lenders in agricultural credit does affect viability of rural financial system. A quick estimate shows that social cost of forgiveness program has been twenty five percent of loan outstanding. On the other hand continued interest of the political lenders in interest and loan forgiveness program also affects expected recovery behavior of the borrowers. Burden of social cost for agricultural or rural credit cannot be fully attributed to crop loans as it constitutes only forty percent of the total agricultural credit. Non crop loans are likely to be less risky. Therefore, the problem of high social cost for agricultural credit can perhaps be linked to institutional behavior.

Mahmud, T., (2006) observed that the rural poor generally have low income to sustain their livelihood. They do not have the capacity to start any income generating activities due to lack of financial capital. They also have very limited access to the formal financial institutions because of the inability to fulfill formal collateral requirement. Thus in order to widen rural poor access to finance, micro credit program has been launched which require no collateral to obtain funds. Tajul Islam, et al. (2010), examine the off farm activities and loan performance evaluation of RSCP (RAKUB Self-Help Credit Program). They found that overall loan disbursement achievement was $90.16 \%$ and loan recovery achievement was $80.02 \%$. Loan outstanding of Paba branch was increased day by day and other indicators of loan performance evaluation were in good position. Among the indicators, a RAKUB loan disbursement activity was more efficient than other indicators followed by loan recovery and loan outstanding. Loan recovery had positive significant effect on loan outstanding and other relating variable such as disbursement, interest charges and time period had no significant effect on loan outstanding.

\section{MeThODOLOGY}

The present study has been carried out to identify the relations of Agro based industries loan to other loans and identifies the contribution of agriculture sector on GDP of Bangladesh on Rajshahi Krishi Unnayan Bank (RAKUB). The present study is diagnostic and exploratory in nature and makes use of secondary data. The relevant data and information were collected from annual reports of this banks, Bangladesh Bank, Bangladesh Bureau of Statistics (BBS) and websites of relevant agricultural banks in Bangladesh. The study is confined only to the specific areas like the loans on different agricultural sectors and the contribution to GDP by the agriculture sector by the Rajshahi Krishi Unnayan Bank for the twelve years period starting from 1998-1999 
to 2009-2010. These data has been analyzed through the various statistical measures like correlation and regression analysis.

\section{RESULTS AND DISCUSSION}

With growing demand of agricultural credit for sustainable agricultural production, Bangladesh bank requires all scheduled banks (SCBs, SBs, PCBs and FCBs) to mobilize credit into agricultural sector. These financial intermediaries have offered short and long term credit according to the purposes of agricultural activities. According to BB recent report, about 63\% (Tk. 52.16 billion) of credit disbursed as short-term lending and the rest $37 \%$ (Tk. 30.63 billion) as in the form of long-term loans. Long term loans are used for purchasing irrigation equipments, agricultural machinery, livestock, horticultures, fisheries, and establishment of agro-based industries etc. Typically, short-term loans are provided for seasonal agricultural production activities.

Table 1: Descriptive Statistics of loan in different sector of agriculture provided by RAKUB.

\begin{tabular}{lccccc}
\hline Statistic & Crops & Fishery & Livestock & $\begin{array}{c}\text { Irrigation equipment } \\
\text { \& farm machinery }\end{array}$ & $\begin{array}{c}\text { Agro based } \\
\text { Industries }\end{array}$ \\
\hline Mean & 3207.77 & 36.35 & 368.53 & 55.89 & 183.49 \\
Standard & 579.93 & 17.34 & 95.66 & 20.63 & 106.00 \\
Deviation & -1.05 & 0.04 & -1.32 & -0.39 & -0.57 \\
Kurtosis & -0.80 & -0.30 & -0.19 & 0.17 & -0.37 \\
Skewness & 2248.00 & 2.50 & 219.90 & 21.00 & 3.70 \\
Minimum & 3825.27 & 65.21 & 507.00 & 92.00 & 342.00 \\
Maximum & & & & & \\
\hline
\end{tabular}

From Table 1, we may conclude that the average loan on ago based industries is 183.49 million Taka (noted that Taka is the unit of Bangladesh currency). The minimum loan on agro based industries was 3.7 million Taka where as the maximum loan was 342 million Taka. On the other hand on an average the maximum loan is given for crops which is 3207.77 million Taka by RAKUB and the minimum loan is given for fishery which is 36.35 million Taka. From Table 1, we also observe that agro based industries are in third position on the basis of giving the highest loan by the bank considered in the study.

Table 2: Correlations among the loans of different sector of agriculture provided by RAKUB

\begin{tabular}{|c|c|c|c|c|c|}
\hline Variables & Crops & Fishery & Livestock & $\begin{array}{l}\text { Irrigation equipment } \\
\& \text { farm machinery }\end{array}$ & $\begin{array}{l}\text { Agro based } \\
\text { Industries }\end{array}$ \\
\hline Crops & 1 & & & & \\
\hline Fishery & $0.874^{* *}$ & 1 & & & \\
\hline Livestock & $0.817^{* *}$ & $0.765^{* *}$ & 1 & & \\
\hline $\begin{array}{l}\text { Irrigation equipment } \& \text { farm } \\
\text { machinery }\end{array}$ & 0.526 & $0.739^{* *}$ & $0.751^{* *}$ & 1 & \\
\hline Agro based Industries & $0.791^{* *}$ & $0.859^{* *}$ & $0.738^{* *}$ & $0.824^{* *}$ & 1 \\
\hline
\end{tabular}

** Correlation is significant at the 0.01 level (2-tailed).

Table 2, shows the correlation matrix of different loans in agriculture sector provided by RAKUB which are the most contributing sector of agriculture in Bangladesh. From Table 2, we may conclude that all the variables are positively correlated to each other i.e., except the correlation between the loan on Crops and the loan on Irrigation equipment $\&$ farm machinery, all the correlation coefficients among the variables considered in this study are statistically significant at 1 percent level of significance. We also observe that loan on Crops is strongly positively correlated with the loans on Fishery and Livestock. Loan on Agro based industries is strongly positively correlated with the loans on Crops, Fishery and Irrigation equipment \& farm machinery where as moderately correlated with the loan on Livestock. 


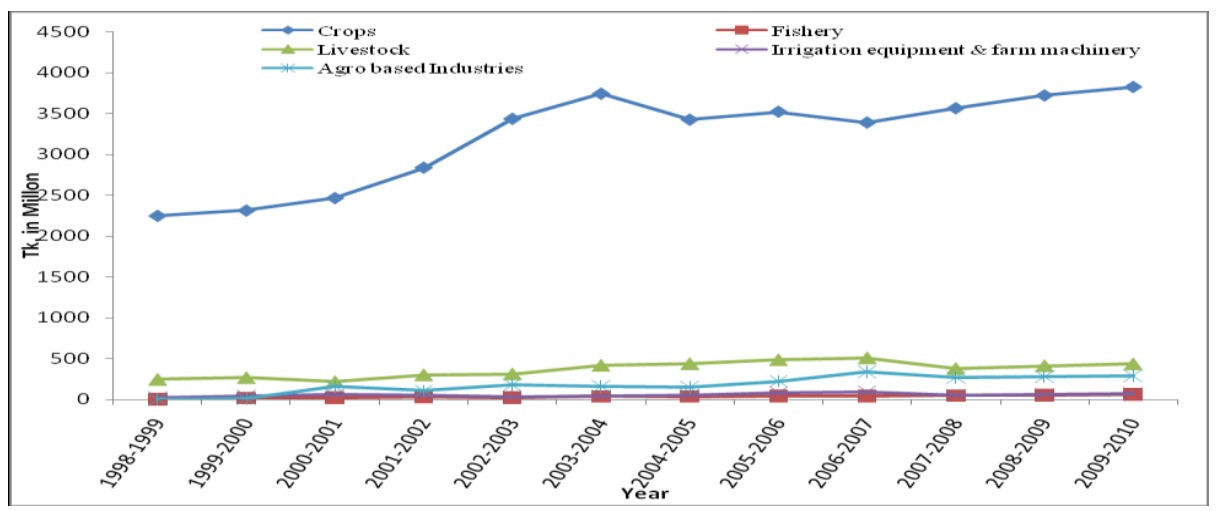

Figure 1: Loan on different sectors of agriculture on 1998-1999 to 2009-2010 by RAKUB.

Figure 1 shows the loans on different sector of agriculture considered in this study during FY 1998-99 to FY 2009-2010 provided by RAKUB. From Figure 1, we observed that loan on Crops is too much higher than the other sector considering in this study. In case of Crops there is upward trend where as on the other sector there is no trend observed. The loan on Fishery and Irrigation equipment \& farm machinery were almost constant for each year considered in this study. The loan on Livestock and Agro based industries increased slightly for some year and in some year it is decreases slightly. The loan on Crops was above 2000 million Taka on 1998-1999 and it reaches to around 4000 million Taka on 2009-2010, whereas loan on other sector were below 500 million Taka over the study period.

\section{Regression Analysis}

Gross Domestic Product (GDP) of Bangladesh depends on so many factors. Agriculture is one of the main contributing sector. Also contribution in GDP by agriculture is depends on different sectors like as Crops, Livestock, Fishery etc. The producer/grower of these sectors has been taken loan from different organizations to maximize their output since they have not enough money for doing these jobs. RAKUB is one of them. Thus we may say that the contribution in GDP by agriculture is affected by the loans of these sectors. In order to determine the relationship between contribution in GDP by agriculture and the loans on different sector of agriculture we use multiple regression model.

Table 3: Different estimates of the multiple regression model.

\begin{tabular}{|c|c|c|c|c|c|}
\hline \multirow{2}{*}{ Variables } & \multicolumn{2}{|c|}{ Coefficients } & \multirow{2}{*}{$\mathrm{t}$} & \multirow{2}{*}{ P Value } & \multirow{2}{*}{ Other estimates } \\
\hline & $\mathrm{B}$ & Std. Error & & & \\
\hline$\overline{\text { Constant }}$ & 23.238 & 4.879 & 4.763 & 0.001 & \\
\hline Loans on Crops $\left(X_{1}\right)$ & 0.019 & 0.002 & 9.627 & 0.000 & \\
\hline Loans on Fishery $\left(X_{2}\right)$ & 0.149 & 0.047 & 3.177 & 0.009 & $\begin{array}{c}R=0.948 \\
\text { R Square }=0.899,\end{array}$ \\
\hline Loans on Livestock $\left(X_{3}\right)$ & 0.018 & 0.005 & 3.539 & 0.005 & $\begin{array}{c}\text { Adjusted R Square }= \\
0.815\end{array}$ \\
\hline $\begin{array}{l}\text { Loans on Irrigation equipment } \& \text { farm } \\
\text { machinery }\left(X_{4}\right)\end{array}$ & 0.065 & 0.025 & 2.567 & 0.026 & $\begin{array}{l}\text { Durbin-Watson } \\
\quad=2.029 \\
F=10.671\end{array}$ \\
\hline Loans on Agro based Industries $\left(X_{5}\right)$ & 0.019 & 0.007 & 2.755 & 0.019 & \\
\hline
\end{tabular}

The regression coefficients and the other estimates are presented in Table 3. The dependent variable is Contribution in GDP by agriculture (CGDPBA) and the independent variables are loans on Crops $\left(X_{1}\right)$, Loans on Fishery $\left(X_{2}\right)$, Loans on Livestock $\left(X_{3}\right)$, Loans on Irrigation equipment \& farm machinery $\left(X_{4}\right)$, and Loans on Agro based Industries $\left(X_{5}\right)$. The coefficient of the regression line showed that there was a significant positive association between the contribution in GDP by agriculture and the loans on Crops, Livestock, Fishery, Irrigation equipment $\&$ farm machinery and Agro based industries with $(F=10.671, p<0.05)$. The $R^{2}$ value indicated that there was an $89.9 \%$ contribution in the overall increasing variation of contribution in GDP due to the independent variables considered in this study. The value of Durbin-Watson is very close to 2, which indicates that there is no autocorrelation problem. These results demonstrated that all the independent variables considered in this study were statistically significant at 5 percent level of significance. The estimated regression equation is 


$$
C G \hat{D P B A}=23.238+0.019 X_{1}+0.149 X_{2}+0.018 X_{3}+0.065 X_{4}+0.019 X_{5}
$$

\section{CONCLUSION}

The agricultural bank has started in Bangladesh in the year 1986. After commencement the agricultural bank is playing a vital role in the economic development of the country. It is reflected from the analysis that almost every year the bank is opening new branches. The bank should open more new branches for the overall development of agricultural sector in Bangladesh. The agricultural bank has created employment opportunities for more than ten thousand people in Bangladesh. Economic development can be accelerated from the agro based industries development. Agriculture products are very demandable in the domestic and international market. Crops, fisheries, livestock and forestation, manufacturing and marketing of agricultural implements are encouraged with agro based loan. The prices of agricultural products are lower than other products so they are disinterested in agricultural production. Bangladesh is based on the raw materials for the agro based industries that is highly demandable in the northern part of Bangladesh about this support come from the RAKUB agriculture bank. We may conclude that all the variables are positively correlated to each other. The coefficient of the regression line showed that there was a significant positive association between the contribution in GDP by agriculture and the loans on Crops, Livestock, Fishery, Irrigation equipment \& farm machinery and Agro based industries. We also make the following suggestions to improve the agriculture sector of Bangladesh which earns more GDP.

\section{Suggestions:}

1. Bangladesh is basically agricultural country so its improvement is essential

2. Farmers development is pin point for economic development in developing country

3. Employment generation need through agro based industries improvement

4. Agricultural products goods should be developed for marketing in easy way

5. Entrepreneurs development need for agriculture sectors development

6. Packaging industries may be considered for agro products progression

7. Bank should provide credit facilities in this sector

8. Government should help for the agriculture entrepreneurs in establishing new industries

9. Important policies and programs should be initiated through Bangladesh bank which have to utilized in developing this sectors

10. Training should be arranged for the entrepreneurs with the support of government in proper way

\section{REFERENCES}

[1] Md. Rashidul Alam Mahumud, Md. Golam Hossian, and Syeda Zabin Nessa Sultana, An Empirical Analysis of the Impact of Agricultural Banking Industry profitability in Bangladesh: An Evaluation of Internal Indicators of RAKUB, International Journal of Science and Research, 2(1), 2013, 558-566.

[2] Rajshahi Krishi Unnayan Bank, Annual Report, 2009-2010.

[3] Afroz, Nushrat Nahida, Agri Business Financing in Bangladesh, a Case Study on Bangladesh Krishi Bank, Europeon Journal of Business and Management, 4(21), 2012, 18-33.

[4] Chowdhury A. and Islam S., Interest Rate Sensitivity of Loans and Advances: A Comparative Study between Nationalized Commercial Banks and Specialized Banks, ASA University Review, 1(1), 2007, 11-28.

[5] Chowdhury, T. and Chowdhury, S., Performance Evaluation of Agricultural Banks in Bangladesh, International Journal of Business and Management, 6(4), 2011, 75-89.

[6] Farid Ahmed M., Some Aspects of Agricultural Credit in Bangladesh, Bureau of Business Research, University of Dhaka, 1980.

[7] Paul, Priya., Brata., The Role of Rajshahi Krishi Unnayan Bank in Agricultural Development of Rajshahi District, The Rajshahi Universiry Studies (Part A), 17, 1989, 7-22

[8] Zahurul Alam and Md. Ruhul Amin, Management of Bangladesh Krishi Bank: Current Issues and Solutions, Islamic University Studies (Part-C), 7(2), 2008, 68-82

[9] Ahmed, S., Some Issues of Institutional Agricultural Credit, The Dhaka University Studies (Part C), 9(1), 1988.

[10] Khalily B., Rasheda H., and Farzana L., On the Behavior of Agricultural Credit in Bangladesh: The Role of Bangladesh Bank, Journal of Business Studies, 18(1), 1997, 131-152.

[11] Mahmud T., Effectiveness of Micro credit for Poverty Alleviation under Agricultural Intensification Projects in Bangladesh, Unpublished PhD Thesis, School of Graduate Studies, University Putra Malaysia, 2006 (available http//Psasir.upm.edu.my).

[12] Tajul Islam, Md. Salauddin Palash and Md. Kamal Uddin, Off-farm activities of Rajshahi Krishi Unnayan Bank: A micro level study, Journal of Subtropical Agricultural Research and Development, 8(6), 2010, 1151-1157. 